\title{
Startups Business Opportunities Analysis as an Effort to Arrange Policy Design for Reducing the Impact of Covid- 19 Pandemic on Startups Business
}

\author{
Anugerah Widiyanto ${ }^{1}$, Anggun Dwi Puspo Supomo ${ }^{2}$, Daru Rahmawati ${ }^{3}$, Djoko Prasetyo ${ }^{4}$ \\ \{anugerah.widiyanto@bppt.go.id ${ }^{1}$, anggun.dwi@bppt.go.id ${ }^{2}$, daru.rahmawati@bppt.go.id ${ }^{3}$, \\ djoko.prasetyo@bppt.go.id ${ }^{4}$ \} \\ 1234 Technology Based Business Incubator, Agency for the Assessment and Application of Technology \\ Puspiptek area, Building 720, Muncul, Serpong District, South Tangerang City, Banten 15314 \\ (+62 21) 75791384 / 7560101, info-bit@bppt.go.id
}

\begin{abstract}
Covid-19 pandemic had an impact on the global economy. Startups played big role in Indonesia's economy. This study was aimed to know the startups business opportunity during pandemic. This study used online questionnaires to the startups under the coordination of the Ministry of Research and Technology. Questionnaire were processed using pivot tables and analyzed by SWOT. Data showed that $79 \%$ startups keep survive despite the pandemic conditions. This study was focus on startups in the field of health/medicine, agriculture/food security, IT, transportation, manufacture, energy. The business sustainability were $95 \% ; 86 \% ; 76 \% ; 75 \% ; 71 \% ; 43 \%$, respectively. The increase number in turnover were $48 \% ; 16 \% ; 11 \% ; 0 \% ; 8 \% ; 0 \%$, respectively. The increase number of labor were $29 \% ; 6 \% ; 7 \% ; 0 \%, 4 \% ; 0 \%$,respectively. SWOT analysis showed that the startups in the field of health/medicine, agriculture/food security, IT and manufacture have business opportunities to develop amid the pandemic. The result of this study was recommended to arrange policy design for reducing the impact of Covid-19 pandemic on startups business.
\end{abstract}

Keywords: business incubator, startups, Covid-19 pandemic, policy design

\section{Introduction}

Coronavirus disease 2019 (Covid-19) was spread in the early 2020. This virus firstly founded in Wuhan, China and as of May $1^{\text {st }} 2020$ there were a total of 84.868 confirmed cases and a total of 6.303 deaths ${ }^{[1]}$. Reported from the official site of

${ }^{1}$ WHO. WHO Coronavirus Disease (Covid-19) Dashboard. https://covid19.who.int/. May $1^{\text {st }} 2020$ (19.00) 
World Health Organization (WHO) that on March $11^{\text {st }} 2020$ WHO made the assessment that Covid-19 could be characterized as a pandemic based on deeply concerned both by the alarming level of spread and severity, and by the alarming levels of inaction. WHO stated that Covid-19 is not just a health crisis but will touch every sector. WHO recommended to countries to take a whole-of-government, whole-of-society approach, built around a comprehensive strategy to prevent infections, save lives and minimize impact. WHO established emergency status for the Covid-19 virus outbreak. Most countries in the world, including Indonesia, are wary of spreading the disease ${ }^{[2]}$.

The Government of Indonesia took step to deal with Covid-19 pandemic by creating large-scale social restriction policy as outlined in Government Regulation number 21 year 2020. Large-scale social restrictions are restrictions on certain activities of residents in an area suspected of being infected with Covid-19 in such a way as to prevent the possibility of spreading the Covid-19 virus ${ }^{[3]}$. This policy was designed to prevent the spread of the covid-19 virus to remote areas in Indonesia. Large-scale social restriction reduce human mobility between regions which will minimize the chance of the virus spread. On the other hand, this policy had an enormous impact to the Indonesian national economy. Many offices both government offices, large companies, including small medium enterprise or startups stopped their business activity during the large-scale social restriction period. Small medium enterprise (SME) reached $98.86 \%$ of the total companies in Indonesia, absorbed about $75.33 \%$ of total workers and contribute around $60.3 \%$ of Gross Domestic Product (GDP) ${ }^{[4]}$.

The Technology Based Business Incubator (BIT) is a technical implementing unit under Agency for the Assessment and Application Technology (BPPT) which carried out technology incubation service activities ${ }^{[5]}$. Based on these condition, Technology Based Business Incubator mapped the impact of the Covid-19 pandemic to the startups business. The Covid-19 pandemic impact mapping activity

\footnotetext{
${ }^{2}$ Budiyanti, E. The impact of the corona virus on the Indonesian trade and tourism sector. Brief information on the actual and strategic issues. 2020. Vol XII No. 4:19.

${ }^{3}$ Government Regulation No 21 of 2020. Large-Scale Social Restrictions in Order to Accelerate Handling of Corona Virus Disease 2019 (Covid-19). Jakarta: Ministry of Law and Human Rights of the Republic of Indonesia. 2020

${ }^{4}$ BPS-statistics Indonesia 2019. Executive Summary of Result of Establishment Data Collection. Economic Census 2016-Continued. 2019

${ }^{5}$ Hamdani, et al. Technology based Incubators Business Process. Jakarta: BIT-BPPT. 2013
} 
was carried out in coordination with the Ministry of Research and Technology / National Research and Innovation Agency (Kemenristek / BRIN) and also the Indonesian Business Incubator Association ( $A I B I)$. The mapping data used to analyze the startups business opportunity as an effort to arrange policy design for reducing the impact of Covid-19 pandemic on startups business.

\section{Method}

The mapping of the impact of the Covid-19 pandemic on startups business was conducted by spread online questionnaires to startups under the coordination of the Ministry of Research and Technology / National Research and Innovation Agency and Indonesian Business Incubator Association. The data were processed using pivot tables and analyzed by SWOT.

\subsection{Identification of the respondent}

Respondents in this study were the startups accompanied by business incubators under the coordination of the Ministry of Research and Technology / National Research and Innovation Agency and Indonesian Business Incubator Association with criteria, such as:

1. Has a technology-based startups

2. The owner or decision maker level

3. Startups with legal status

4. Operate for at least one year

\subsection{Questionnaires data collection}

Questionnaires were distributed online using the google form link to the identified respondent. Questionnaire distribution conducted during the period of April $9^{\text {th }}-30^{\text {th }} 2020$. The questionnaire contained about:

1. Startups profile

2. Business sustainability during Covid-19 pandemic

3. Covid-19 impact to the startups business

\subsection{Data processing and analysis}


Data obtained from online questionnaires were processed using pivot table to group and summarize data. Data grouping was done to obtain the summary data about:

1. Distribution of respondent location

2. Business field

3. Business sustainability

4. The impact on turnover and labor

5. Availability of innovation

6. Business barrier

Data summary was used as a basis for SWOT analysis by considering internal and external factors. Internal factor contain the strengths and weakness of the startups during Covid-19 pandemic while external factors contain opportunities and threats that will affect the sustainability of the startups during Covid-19 pandemic.

\section{Result and Discussion}

\subsection{Startups Profile}

Coordination in determining respondents was conducted with the Ministry of Research and Technology / National Research and Innovation Agency and Indonesian Business Incubator Association to obtain the database of business incubators in Indonesia. The distribution online questionnaire to startups was facilitated by the business incubators. The questionnaire contained 25 questions divided into 3 sections, including startups profile, business sustainability, and the impact of the Covid-19 pandemic on business startups. The questionnaire is a questionnaire with open and closed questions. Closed questions are made using a serial scale, to obtain data that if processed shows the level of respondents' perceptions about the measured variable. Whereas open-ended questions are needed to support qualitatively from quantitative data obtained and finally can be used as managerial implications ${ }^{[6]}$. The total number of respondent filled online questionnaire during the period of April $9^{\text {th }}-30^{\text {th }} 2020$ totaled 151. Respondents were scattered in various regions in Indonesia according to the distribution of their incubators as shown in the figure 1. The wide distribution of respondent's locations

\footnotetext{
${ }^{6}$ Sugiyono. Quantitative, Qualitative and R\&D Research Methods. Bandung: Alfabeta. 2009
} 
increased the accuracy of the data in the analysis of startups business opportunity during Covid-19 pandemic because the impact data of the pandemic not only obtained from one regional area. Thus, the distribution was considered to be sufficient to represent the startups conditions during Covid-19 pandemic from all over Indonesia.

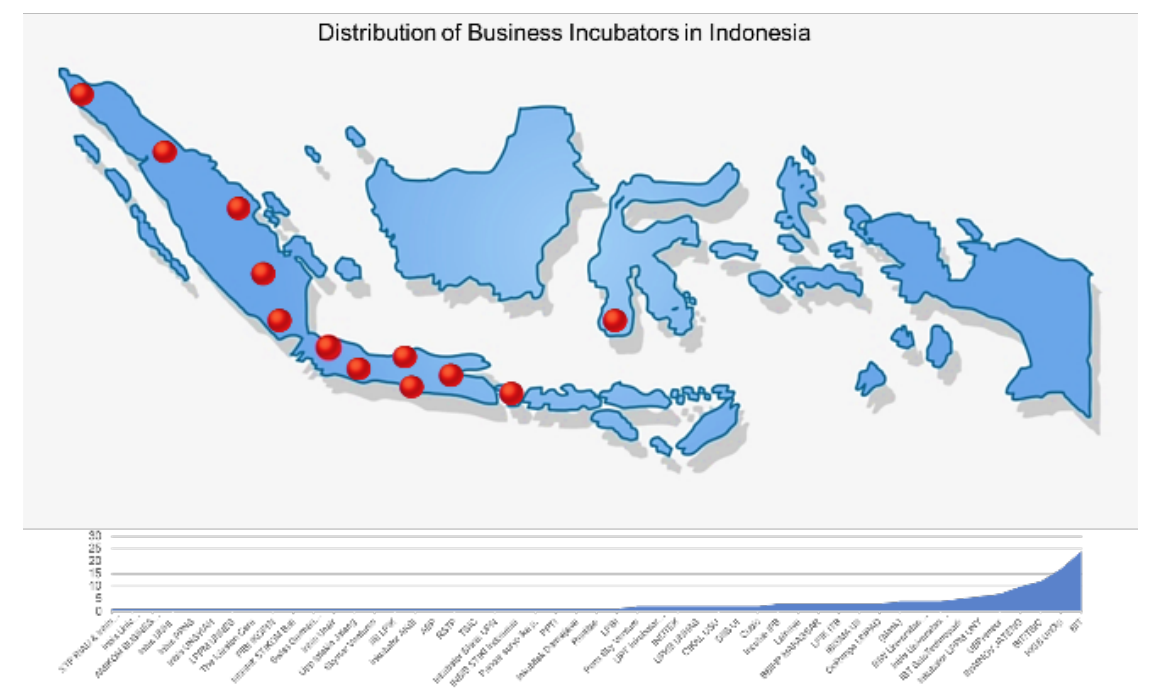

Figure 1. Distribution of Business Incubators in Indonesia.

The online questionnaire also mapped out the startups business field to see startups business opportunities in the midst of the Covid-19 pandemic. The business fields were based on the National Research Excellence Program listed in the National Research Master Plan 2017 - 2045, namely:

1. Agriculture / food security

2. Energy

3. Information technology

4. Advanced material / manufacture

5. Health / medicine

6. Transportation technology

7. Defense and security technology ${ }^{[7]}$

\footnotetext{
${ }^{7}$ Ministry of Research, Technology and Higher Education. National Research Master Plan 2017-2045. Jakarta:
} Ministry of Research, Technology and Higher Education. 2017 
Questionnaire entries from 151 startups illustrated the distribution of startups in Indonesia as shown in figure 2. Startups in the field of agriculture / food security, IT, manufacturing, health / medicine dominate the number of startups in Indonesia, $23 \%$ in average. While startups engaged in energy, transportation technology and defense and security technology were in small amount $\leq 5 \%$.

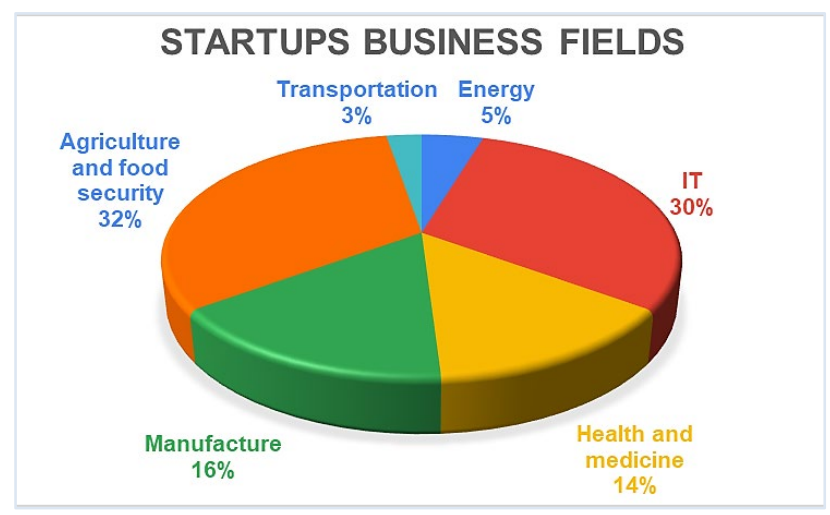

Figure 2. Startups Business Fields in Indonesia.

Respondents in filling out this online questionnaire were startups assisted by business incubators or 'tenant', who participated in the technology business incubation program at each incubator. Technology business incubation is a process of guidance, assistance and development carried out by business incubators to their tenant ${ }^{[8]}$. Respondents of this activity were mapped based on the year of graduation from the technology business incubation program to illustrate the level of business maturity in the face of Covid-19 pandemic. The graduation year graph as shown in figure 3 showed that the range of startups graduation years between 2015-2020 had a majority of tenants who graduated in 2019 .

\footnotetext{
${ }^{8}$ Regulation of the Head of the Technology Incubator Center No. 1 of 2019. General Provisions and Guidelines for the Implementation of Technology Business Incubation Services. Technology Incubator Center. Jakarta. 2019
} 


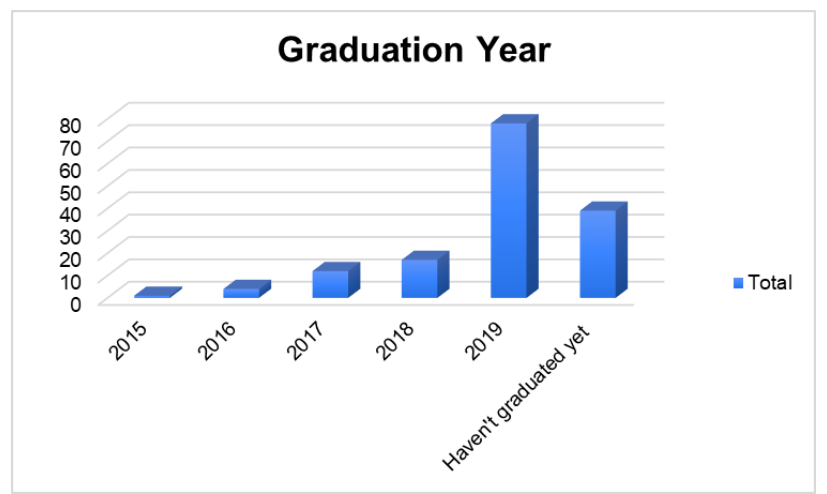

Figure 3. Graduation year of startups under business incubation program.

Tenants were declared 'graduated' when they meet the exit policy criteria and were judged to be able to compete in the open market. The proportion between graduated startups and non-graduated startups was $74 \%: 26 \%$. This showed that the number of startups that have competitiveness and endurance were at a greater number. An analysis of the impact of the Covid-19 pandemic on the startups business was more relevant because the analysis is carried out on startups that are considered to have competitiveness thereby reducing other factors to consider.

\subsection{Business sustainability}

Covid-19 pandemic affected many business sectors. The enactment of Indonesian government policies in the form of large-scale social restriction caused impeded mobility of goods and services which also affect the national economy. The result of monitoring the impact of Covid-19 on the startup business through questionnaires that have been conducted showed that $79 \%$ respondents or startups continue to do their business while another $21 \%$ stop operating their business. The value of business sustainability was explained in figure 4 where several business fields are still capable of doing business amid pandemic conditions. In detail, the business sustainability in the field of health / medicine, agriculture / food security, IT, transportation, manufacture, energy were $95 \% ; 86 \% ; 76 \% ; 75 \% ; 71 \% ; 43 \%$, respectively. The transportation sector had a substantial business sustainability value of $75 \%$, even so startups engaged in transportation have a small number. While startups in the others business fields with business sustainability value above $70 \%$, such as health/medicine, agriculture / food security, IT, manufacture were 
found in greater numbers. The energy sector looked the most difficult to adapt to pandemic conditions because this sector not directly related to community.

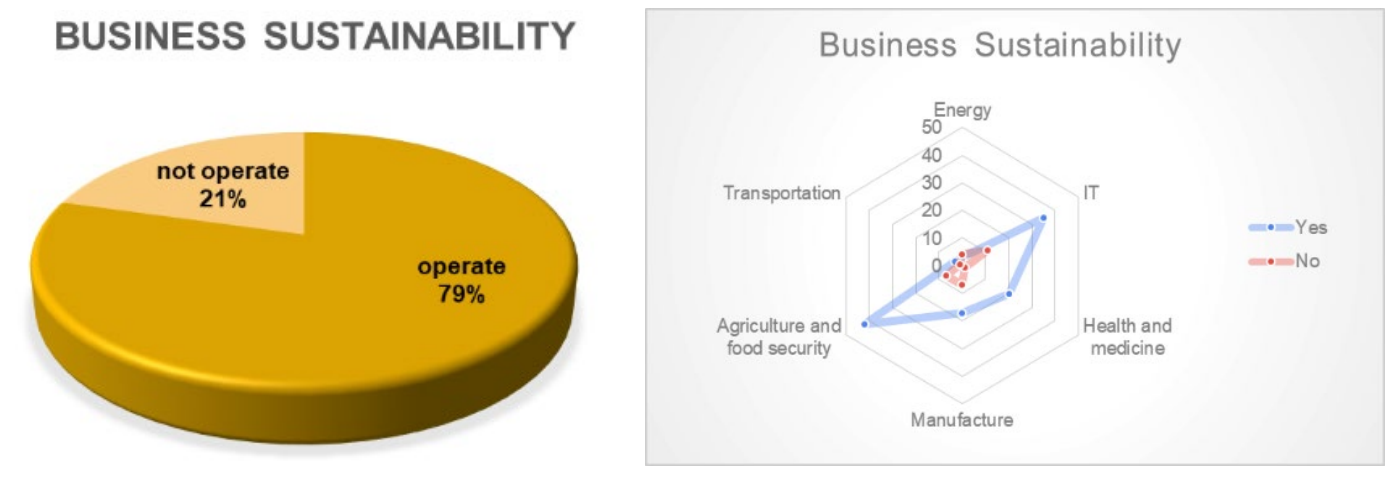

Figure 4. Business sustainability of business startups.

This information showed that startups engaged in these four fields have good opportunities in dealing with a crisis or pandemic situation such as the Covid-19 pandemic. These business fields directly related to the primary needs in the daily life of the community, so the business sustainability level of these fields remains high despite the crisis conditions. The fields of agriculture / food security, IT, health/medicine, and manufacture were business fields that allow rapid changes in business models to adjust to market demand in pandemic conditions.

\subsection{Covid-19 impact to startups business}

The impact of the covid-19 pandemic on startup business can be seen from the business sustainability and its effect on turnover, labor and changes in business models. Pandemic conditions greatly affect the company's business cash flow, especially startups or small and medium-sized enterprise. Retrieval of data related to the impact of the pandemic on turnover of startups came from 151 startup respondents who have filled out online questionnaires. The results of the questionnaire as shown in Figure 5 showed that the majority of startups experienced a turnover decrease of $61 \%$. But the pandemic also had an impact on the increase in startup turnover where there were $17 \%$ of startups with an increase in turnover. Only $2 \%$ of the total respondents stated that there was no impact from the pandemic on their company turnover. The rest of the other respondents did not mention the answers on the questionnaire. 


\section{IMPACT ON TURNOVER}

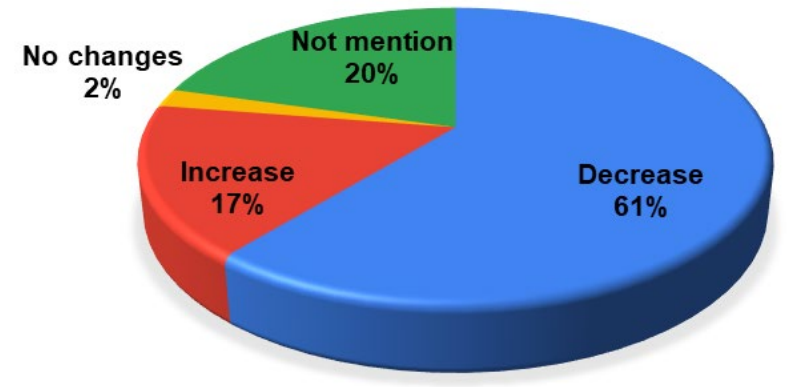

Figure 5. Impact Covid-19 pandemic on startup's turnover.

Increase in turnover during the pandemic experienced by startups engaged in health / medicine, agriculture / food security, IT, and manufacture with a percentage of $48 \% ; 16 \% ; 11 \% ; 8 \%$; of total respondents as shown in figure 6 .

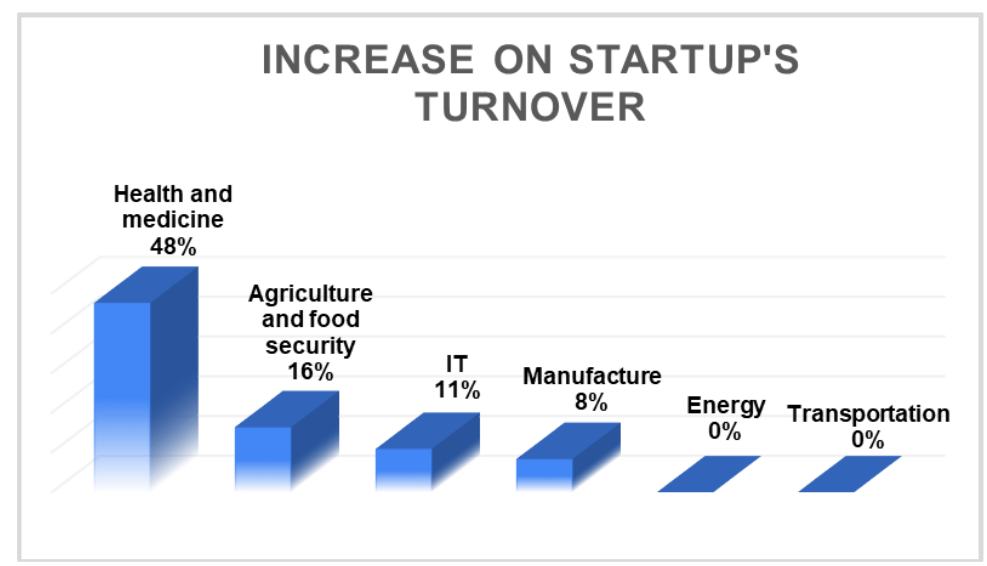

Figure 6. Increase on startups turnover during pandemic.

In more detail as shown in figure 7 , the increase in startup turnover in health/medicine was on average greater than $30 \%$. The health / medicine sector was the business sector that quickly adapted to pandemic conditions in accordance with changing market demand. The fields of agriculture / food security, IT and manufacturing have experienced an average turnover of $10-20 \%$. 


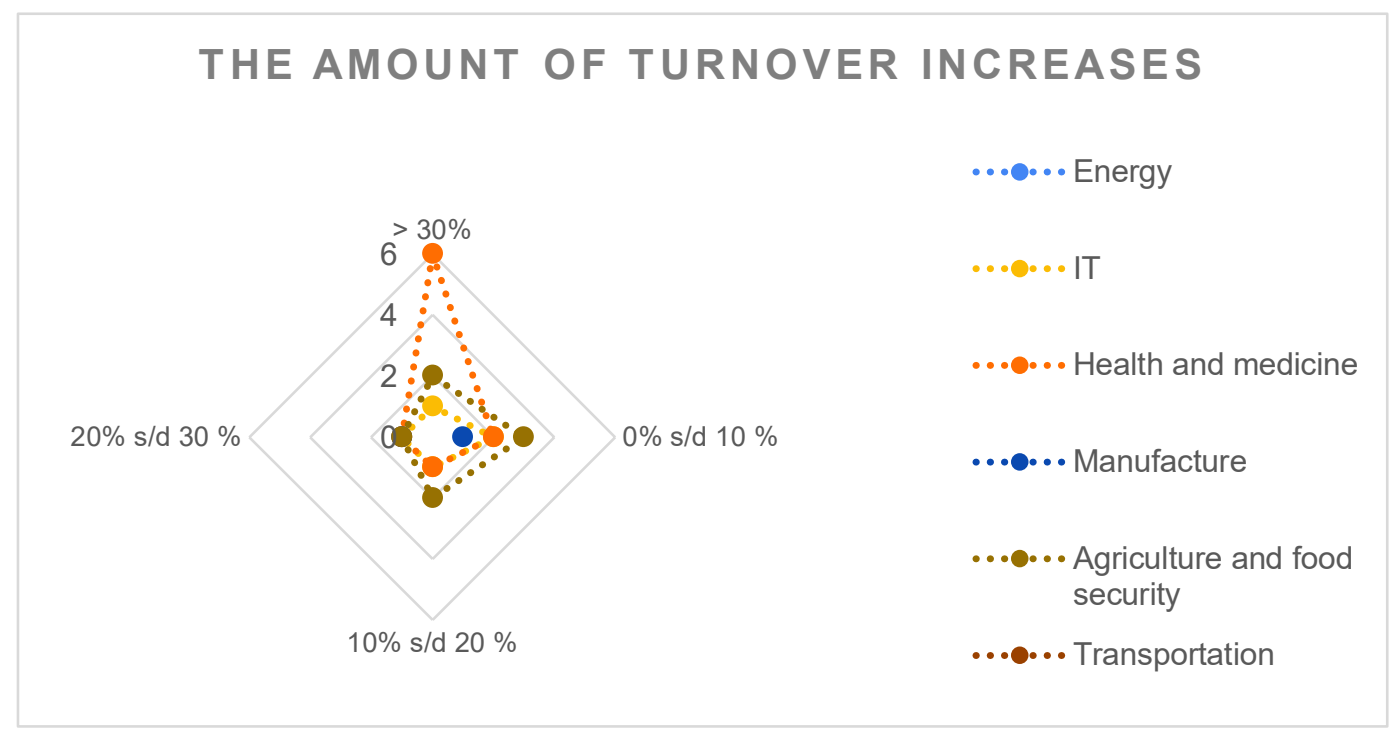

Figure 7. The increase of startup's turnover during pandemic.

The Covid-19 pandemic also caused an impact on the labor within the company. The non-smooth company's cash flow encourages companies to improve operational cost efficiency, one of which is labor efficiency. Cases of termination of employment contracts or temporary lay-offs occurred in large numbers. According to data from the Ministry of Manpower as of May $27^{\text {th }} 2020$, more than 1.7 million workers had to be terminated or laid off from their companies ${ }^{[9]}$. While the data (figure 8) obtained from this study's questionnaire showed that startups that reduced their labor by $37 \%$ during the Covid-19 pandemic period. This amount is greater than startups that are not affected by their labor during a pandemic, which is $33 \%$. However, some startups added labor during the pandemic by $9 \%$ of the total respondents. The addition of this labor as feedback to meet consumer needs and market demand.

\footnotetext{
${ }^{9}$ Juaningsih, Imas Novita. Analysis of lay-off policies for workers during the Covid-19 pandemic in Indonesia. Adalah: Law and Justice Bulletin. 2020; Vol 4 No 1.
} 


\section{IMPACT ON LABOR}

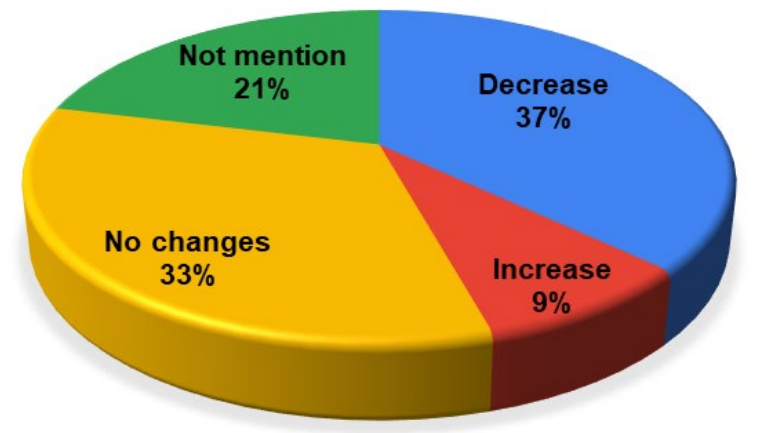

Figure 8. Impact Covid-19 pandemic on startup's labor.

In more detail, the impact of the Covid-19 pandemic on a startup's workforce was explained in Figure 9. The increase in the number of workers during the pandemic experienced by startups engaged in health / medicine, IT, agriculture/ food security, and manufacturing with a percentage of $29 \% ; 7 \% ; 6 \% ; 4 \%$, respectively.

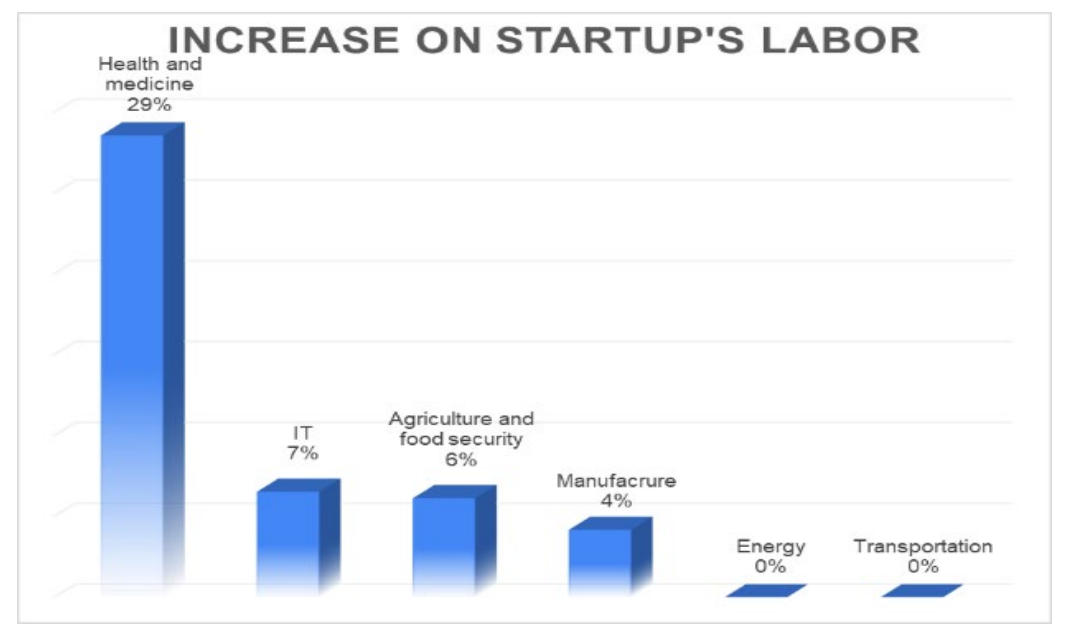

Figure 9. Increase on startup's labor during pandemic. 
An increase in the number of workers in a startup indicated business opportunities amid a pandemic. Startups that added labor to their company will increase the company's operating costs. The guarantee for startups to add labor and increase operational costs is the existence of market certainty during a pandemic. Startups did business development or product / service innovation to get market opportunities. Questionnaire from respondent as shown in Figure 10 showed that some startups or respondents are doing business innovation amid a pandemic. As many as $46 \%$ of startups innovated products / services in their business lines to adjust to market demand during the pandemic.

\section{STARTUPS INNOVATION}

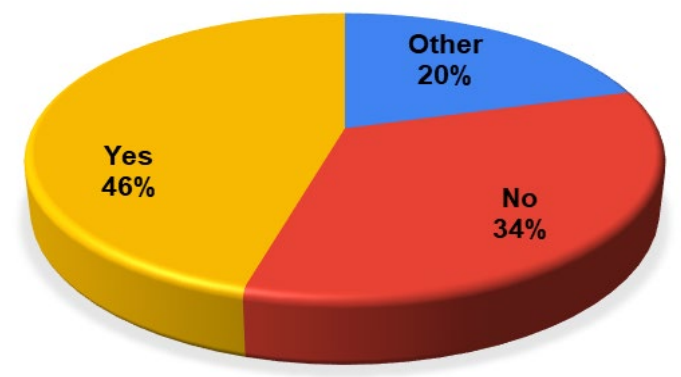

Figure 10. Startups innovation during pandemic.

Of the $46 \%$ of startups that carried out business innovation, startup in the field of agriculture / food security is the largest number about $36 \%$. Startups in this field innovated products related to herbal products or fresh agricultural products that raise health issues. This adjusted to the new normal society in the middle of the pandemic who want products that have health benefits. IT startups (about 32\%) innovated to match the needs of the community during a pandemic where community mobility is low and requires an online system to meet daily needs. Some startups make innovations to facilitated online shopping, online meetings, and online learning. Health/medicine were business sectors directly related to the handling of the Covid-19 pandemic. As many as $20 \%$ of startups in this field were developing medicine products and medical devices, such as hand sanitizers, health supplements and other health services. In addition, the manufacturing and transportation sectors each $10 \%$ and $1 \%$ innovate amid a pandemic to adjust market conditions (Figure 11). 


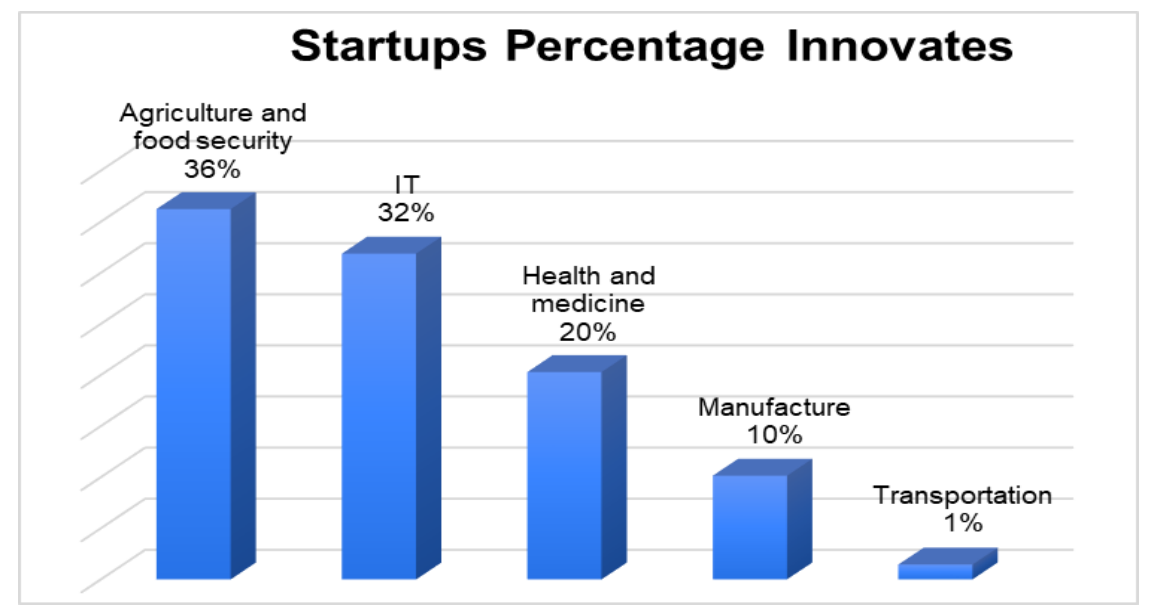

Figure 11. The percentage of startups who innovate during pandemic.

\subsection{SWOT analysis of startups business during pandemic}

SWOT analysis is a type of analysis based on logic that can maximize strengths and opportunities, but simultaneously minimize weakness and threats ${ }^{[10]}$. The SWOT analysis in this study was based on the results of questionnaire respondents. SWOT analysis results showed several points, such as:

1. Business fields that have the opportunity to survive and develop

2. A steps for startups to survive and develop

3. Role recommendations for business incubators in conducting business assistance to their tenants

According to Ilham Habibie, one of technology expert in Indonesia stated that the pandemic had three main effects. First, the effect of the de-globalization that related to the strict entry and exit protocols so that the global supply chain will change. As a result, there will be a development of suppliers from within the country so it is expected that the resilience of domestic supply must be stronger. Second, the effect of service trends based on internet of things (IoT) data which means that services that utilize digital technology are increasingly needed.

\footnotetext{
${ }^{10}$ Rangkuti, Freddy. SWOT Analysis of the Technique for Dissecting Business Cases. Jakarta: Gramedia.. 2013
} 
Pandemic carried limitation in terms of physical interaction so that the use of digital technology is absolutely necessary to replace physical interaction. The third effect due to the pandemic conditions was the business model that changes to follow the new normal. Businesses must find a new business model to be able to adapt to new normal in order to survive which is called the "crash innovation', the fast and sudden innovation ${ }^{[11]}$.

Table 1. SWOT Matrix analysis of startups business during pandemic.

\begin{tabular}{|c|c|c|}
\hline External Factors & $\begin{array}{l}\text { Strengths (S) } \\
\text { 1. Most of PPBT is engaged in agriculture/food security, IT, } \\
\text { manufacturing, health/medicine, and } 79 \% \text { PPBT are still doing } \\
\text { business amid the Covid-19 pandemic } \\
\text { 2. } 70 \% \text { of PPBT in the field of Health/medicine experienced an } \\
\text { increase in turnover on average }>30 \% \text { and the addition of an } \\
\text { average workforce of } 2 \text { people } \\
\text { 3. } 56 \% \text { of PPBT's turnover increased product innovation during } \\
\text { the Covid-19 pandemic } \\
\text { 4. Incubator assistance Mostly continued during the Covid- } 19 \\
\text { pandemic by strengthening the selection system and the } \\
\text { incubation system (in wall / online) } \\
\text { 5. PPBT business is in the fast growing category, more flexible } \\
\text { in change }\end{array}$ & $\begin{array}{l}\text { Weakness(W) } \\
\text { 1. Less than } 10 \% \text { of PPBT engaged in } \\
\text { transportation and energy experienced } \\
\text { difficulties in running a business } \\
\text { 2. Limitations in product sales } \\
\text { 3. More than } 40 \% \text { of PPBT in agriculture/food } \\
\text { security, manufacturing has decreased the } \\
\text { number of workers } \\
\text { 4. } 70 \% \text { of PPBT that experienced a turnover } \\
\text { decreased those who did not innovate } \\
\text { products during the Covid-19 pandemic } \\
\text { 5. Limitation of incubator interaction with } \\
\text { PPBT and limited quality of human } \\
\text { resources }\end{array}$ \\
\hline $\begin{array}{l}\text { Opportunity }(\mathrm{O}) \\
\text { 1. Public awareness of health and technology } \\
\text { is increasing } \\
\text { 2. Changes in business patterns online } \\
\text { during the Covid-19 pandemic or the use } \\
\text { of electronic systems and transactions } \\
\text { 3. Business direction for B2B or B2G is } \\
\text { more promising than retail business } \\
\text { 4. The effects of de-globalization after the } \\
\text { pandemic, protocols in and out of the } \\
\text { country increasingly stringent. } \\
\text { Strengthening of domestic suppliers } \\
\text { F. Predictions of Indonesia's economic } \\
\text { growth remain positive }\end{array}$ & $\begin{array}{l}\text { Strategy SO } \\
\text { 1. Facilitating product and market development by utilizing } \\
\text { business networks and distribution through electronic } \\
\text { transaction systems in the fields of health/medicine, } \\
\text { agriculture/food security, and IT (S1, S2, S3, S4, S5, O1, O2, } \\
\text { O3) } \\
\text { 2. Strengthening coordination of incubators and related } \\
\text { institutions to encourage PPBT products as local suppliers } \\
\text { with B2B and B2G systems }\end{array}$ & $\begin{array}{l}\text { Strategy WO } \\
\text { 1. Facilitating the development of Covid-19 } \\
\text { impacted PPBT business models for business } \\
\text { improvement by adjusting market conditions } \\
\text { (W1, W2, W3, W4, W5, O2, O3, O4) } \\
\text { 2. Strengthening the capacity of HR incubators } \\
\text { through the incubator and facilitator } \\
\text { certification system } \\
\text { (W5, O1, O2, O3, O4, O5) }\end{array}$ \\
\hline $\begin{array}{l}\text { Threat(T) } \\
\text { 1. Crash Innovation (rapid and sudden } \\
\text { innovation) must be adapted quickly by } \\
\text { business people } \\
\text { 2. The negative effects of applying CBSC to } \\
\text { the economy } \\
\text { 3. An increase in the number of layoffs, a } \\
\text { reduction in the level of public and } \\
\text { government consumption and GDP } \\
\text { 4. The availability of qualified PPBT } \\
\text { candidates } \\
\text { D. Decreased level of investment }\end{array}$ & $\begin{array}{l}\text { Strategy ST } \\
\text { 1. Facilitating the development of the PPBT business model to } \\
\text { be flexible to crash innovation in accordance with conditions } \\
\text { due to government policy to overcome Covid-19 } \\
\text { ( } 33, \mathrm{~S} 4, \mathrm{~S} 5, \mathrm{~T} 1, \mathrm{~T} 2, \mathrm{~T} 3, \mathrm{~T} 4, \mathrm{~T} 5) \\
\text { 2. Strengthening the coordination of incubators and related } \\
\text { institutions in suppressing market prices to maintain the level } \\
\text { of public consumption } \\
\text { (S4, S5, T3, T4, T5) } \\
\text { 3. Strengthening the incubation protocol, both in the selection } \\
\text { and incubation stages (in wall / online) to produce quality } \\
\text { PPBT candidates (S4, S5, T3, T4, T5) }\end{array}$ & $\begin{array}{l}\text { Strategy WT } \\
\text { 1. Strengthening incubator coordination for } \\
\text { access to capital as an effort to maintain the } \\
\text { existence of PPBT } \\
\text { (W3, W4, W5, T4, T5) }\end{array}$ \\
\hline
\end{tabular}

${ }^{11}$ Habibie, I. Startup and MSME Strategies Survive, Revive, and Succeed in managing the business of the Covid-19 pandemic. Indonesian SME Webinar Rises amid Corona Pandemic. Bogor: STPIPB. 2020 
The SWOT matrix, as shown in figure 12 above, shows that businesses in the fields of health / medicine, IT, agriculture / food security, and manufacture have the potential to survive and develop. This can be seen from the high survival rate (more than $70 \%$ ), the presence of positive rate of increase in turnover and labor. External factors in terms of opportunities and threats, startups can use business-to-business sales systems and the use of online or electronic transaction systems. Another opportunity for startups in the midst of a pandemic conditions was an import restriction policy by the government. The import restriction was carried out to suppress the flow of goods and human traffic between countries as an anticipatory measure the virus spread between countries. This increases the opportunity for startups to make their products as substitute the imported products. Startups also have the potential to develop business models by adjusting the market conditions. The pandemic conditions increased public awareness of products related to health and hygiene issues in the context of controlling the spread of the virus. The technology business incubator also has a role to do business assistance by paying attention to the strengths, weaknesses, opportunities and threats that exist in their tenants. The results of the SWOT analysis also provide recommendations for incubators in conducting business assistance to tenants.

\section{Conclusion}

Covid-19 pandemic had a very broad impact on people's lives. Health and economic aspects were the main things that are considered by the government. This study focuses on analyzing the economic impact caused by the Covid-19 pandemic on startup businesses in Indonesia. The data collection method used an online questionnaire to startups assisted by incubator under the coordination of the Ministry of Research and Technology / National Innovation Research Agency and the Indonesian Business Incubator Association. The results of the impact analysis of the Covid-19 pandemic on turnover and startup labor showed that startup businesses in the fields of health / medicine, IT, agriculture / food security, and manufacture have the potential to survive and develop amid pandemic conditions. These four business areas were more flexible to adapt to pandemic conditions through product innovation in their business model. The mapping of startups and business opportunities in this study can be used further in the preparation of policy design for incubators in business assistance to the fostered startups. 


\section{Acknowledge}

The authors warmly thank to Ministry of Research and Technology / National Innovation Research Agency and the Indonesian Business Incubator Association for their support.

\section{References}

[1] WHO. WHO Coronavirus Disease (Covid-19) Dashboard. https://covid19.who.int/. May $1^{\text {st }}$ $2020(19.00)$

[2] Budiyanti, E. The impact of the corona virus on the Indonesian trade and tourism sector. Brief information on the actual and strategic issues. 2020. Vol XII No. 4:19.

[3] Government Regulation No 21 of 2020. Large-Scale Social Restrictions in Order to Accelerate Handling of Corona Virus Disease 2019 (Covid-19). Jakarta: Ministry of Law and Human Rights of the Republic of Indonesia. 2020

[4] BPS-statistics Indonesia 2019. Executive Summary of Result of Establishment Data Collection. Economic Census 2016-Continued. 2019

[5] Hamdani, et al. Technology based Incubators Business Process. Jakarta: BIT-BPPT. 2013

[6] Sugiyono. Quantitative, Qualitative and R\&D Research Methods. Bandung: Alfabeta. 2009

[7] Ministry of Research, Technology and Higher Education. National Research Master Plan 2017-2045. Jakarta: Ministry of Research, Technology and Higher Education. 2017

[8] Regulation of the Head of the Technology Incubator Center No. 1 of 2019. General Provisions and Guidelines for the Implementation of Technology Business Incubation Services. Technology Incubator Center. Jakarta. 2019

[9] Juaningsih, Imas Novita. Analysis of lay-off policies for workers during the Covid-19 pandemic in Indonesia. Adalah: Law and Justice Bulletin. 2020; Vol 4 No 1.

[10] Rangkuti, Freddy. SWOT Analysis of the Technique for Dissecting Business Cases. Jakarta: Gramedia.. 2013

[11] Habibie, I. Startup and MSME Strategies Survive, Revive, and Succeed in managing the business of the Covid-19 pandemic. Indonesian SME Webinar Rises amid Corona Pandemic. Bogor: STPIPB. 2020 